\title{
Ko te Rākau Hei Tohu Mō te Rangahau Me te Tuhi Whakapapa: Tree Symbolism as a Method for Researching and Writing Genealogy
}

\author{
Helene Connor
}

\section{check for}

updates

Citation: Connor, Helene. 2021. Ko te Rākau Hei Tohu Mō te Rangahau Me te Tuhi Whakapapa: Tree Symbolism as a Method for Researching and Writing Genealogy. Genealogy 5: 29. https://doi.org/ 10.3390/genealogy5020029

Received: 21 February 2021

Accepted: 23 March 2021

Published: 25 March 2021

Publisher's Note: MDPI stays neutral with regard to jurisdictional claims in published maps and institutional affiliations.

Copyright: (C) 2021 by the author. Licensee MDPI, Basel, Switzerland. This article is an open access article distributed under the terms and conditions of the Creative Commons Attribution (CC BY) license (https:/ / creativecommons.org/licenses/by/ $4.0 /)$.
School of Māori and Indigenous Studies, Faculty of Education and Social Work, University of Auckland, Auckland 1150, New Zealand; h.connor@auckland.ac.nz

\begin{abstract}
This article discusses a method for researching and writing whakapapa (genealogy) based on the symbolism of the tree. Utilizing tree symbolism as a method for researching and writing genealogy is conceived as a literary device for documenting both individual and collective life histories. It is an approach that was developed as being distinctively Māori, but at the same time able to be adapted by other ethnic groups and communities. The method consists of the following aspects of tree symbolism: the roots (family heritage); the trunk (what sustains and gives purpose to one's life); the branches (the different paths our lives follow); the fruits (what we bring to our maturity); the forest (connections with others). Tree symbolism can be adapted for any ethnic group by utilizing the metaphor of a tree that has particular relevance to the particular group. It can also be adapted for community groups. For the most part, though, this article will focus on the Totara tree and its significance around researching and writing about whakapapa for Māori.
\end{abstract}

Keywords: whakapapa (genealogy); family tree; Māori; writing life stories; story-telling; tree symbolism

\section{Introduction}

Researching and writing about whakapapa (genealogy) will inevitably involve storytelling. For many Māori researchers, story-telling holds both method and meaning and is crucial to indigenous research (Tocker 2017). Implicit within the method of story-telling for Māori and other indigenous researchers is the recognition that stories both contain and maintain cultural values, histories, and traditional knowledge. In traditional Māori society, stories were perceived as an important mode of transmitting knowledge including knowledge about whakapapa and family history (Mark and Boulton 2017).

Essential elements in indigenous research include the creation and development of culturally appropriate methodologies and methods and the privileging of indigenous voices (Mark and Boulton 2017). Story-telling as a research method for Māori enables participants to maintain autonomy and authenticity. For Māori researching and writing whakapapa, story-telling as a qualitative research method ensures a Māori world view is upheld within a context that values Māori tikanga (culture) and te reo Māori (Māori language). This article examines the method of story-telling utilizing the metaphor of the tree as a way of keeping tradition alive in a culturally appropriate way.

Ko te rākau hei tohu mō te rangahau me te tuhi whakapapa is a method for writing whakapapa (genealogy) based on the symbolism of the tree. An explanation of each of the Mãori words in the title of the method are outlined below to provide an accurate translation and to enhance understanding: Ko-focus particle; te-the (singular); rākau-(noun) tree; hei(particle) as; tohu-(noun) symbol; mō (particle) about; rangahau -research; tuhi (verb) to write, record and whakapapa-(noun) genealogy. The English translation in its entirety can be read as: tree symbolism as a method for researching and writing genealogy.

The method can be used to document both individual and collective life histories and can also provide a useful literary device for organising aspects of life stories into various themes. 
Trees can outlast generations and have often been used as genealogical reference points, and in many cultures, genealogies have been depicted in images of family trees. Ko te rākau hei tohu mō te rangahau me te tuhi whakapapa can be adapted for any ethnic group by utilizing the metaphor of a tree that has particular relevance to the group. For example, the English Oak tree is woven into the folklore and history of England. Druids would worship in oak groves and acorns; the fruits of the oak were frequently carried as good luck charms (Castelow n.d.). The English Oak is revered as an ancient symbol of strength and longevity and frequently appears as a symbol of family history (Caro n.d.).

Ko te rākau hei tohu mō te rangahau me te tuhi whakapapa-Tree symbolism as a method for researching and writing genealogy uses the symbolism of the roots, the trunk, the branches, the fruits and the collective forest to represent life narratives. It can also be adapted for community groups. This article focuses on both individual and collective life stories utilizing the Tōtara tree, a very significant tree for Māori and one, that is an ideal tree to symbolize whakapapa (genealogy).

Ko te rākau hei tohu mō te rangahau me te tuhi whakapapa and the Symbolism of Trees

Conceptions of trees as having cosmological meanings are well known in many world religions and indigenous cultures (Ratka 2017). The symbolism of the tree of life, for example, is often referred to as the 'world tree' or 'shamanic tree' and is connected with various forms of mystic-religious experiences considered to be cross-cultural phenomena (Ratka 2017). The tree of life is is often linked with a "centre" of the earth. It is probably the most ancient universal human myth (Crews 2003).

The tree of life for the Celtic Druids was the oak. Oaks were also associated with the gods Zeus, Jupiter and Thor. Symbolically, oaks are associated with longevity, strength, stability, endurance, fertility, power, justice and honesty (Leroy et al. 2019).

Māori also associated trees with the atua (gods). Tāne-Mahuta is the Atua of the forest and features in many iwi (tribal) creation stories as the god who separated the primal parents, Ranginui (sky father) and Papatūānuku (earth mother), and brought about Te Ao Mārama, the world of light and life, (Pomare and Cowan 1930). Another creation narrative has Tane-Mahuta fashioning the first woman, Hine-ahu-one, from kurawaka, (sacred red clay) from Papatūānuku (Pomare and Cowan 1930).

In Te Ao Māori (the Māori world) the forest is known as Te Wao-tapu-nui-a-Tane (the vast sacred woods of Tanne-Mahuta) and the trees of the forest are perceived as being the children of Täne-Mahuta. The bark of trees is Te kiri-o-Täne-Mahuta (the skin of the lord of the forests). Te riu-o-Tāne-Mahuta (the hollow trunk of Tāne-Mahuta is applied to a canoe, a chopped-out tree log (Pomare and Cowan 1930).

The Tōtara was an especially valued tree for Māori. When this child of Tāne-Mahuta, or any other large tree, was felled, a ritual was performed and fronds of fern were laid on the stump to cover the raw, naked wounds of Tāne-Mahuta (Pomare and Cowan 1930). The Tōtara belongs to the Podocarpaceae, the dominant family of southern hemisphere conifers. An immense tree of the podocarps it can grow well over $40 \mathrm{~m}$ tall with its trunk up to $4 \mathrm{~m}$ in diameter (Simpson 2017). The Tōtara can be viewed as symbolizing life and the continuity of blood lines. The Tōtara was accorded divine status by Māori, based on its immense size and its use in making waka (canoe) employed on long, dangerous voyages (Simpson 2017). When the Tōtara is carved it can serve as a visual representation of ancestry and historical and mythological events. The Tōtara can also be perceived as representing a connection between the past and the present, the secular and the spiritual. It has a strong connection to Māori creation stories as it reaches down to Papatūānuku (Mother Earth) and up towards Ranginui (Sky Father). It represents whakapapa and as such can be viewed as an ancestral tree and is thus a fitting and powerful symbol for Māori auto/biography, narratives, pūrākau (stories) and life histories (Connor 2006).

Whakapapa, for Māori, is a concept that blends the term, whaka (a liminal process of becoming) and the term, papa (something broad or flat such as a rock or board), to describe how our foundation as a people has come to be (Hudson et al. 2007, p. 44). Whakapapa provides a framework for Māori to explain concepts and narratives fundamental to our 
culture, identity, language, spirituality and worldview (Connor 2019; Hudson et al. 2007; Mahuika 2019). Whakapapa is what connects all Māori to one another and is the central marker of traditional matauranga Māori (Māori knowledge) (Clarke 2006).

The symbolism of the Tôtara and how it can be used to document life narratives (both collective and individual is divided into: the roots (family heritage); the trunk (what sustains); the branches (the different paths our lives follows); the fruits (what we bring to maturity); the forest (connections with others). This section outlines the symbolism of the Tōtara and the following section provides examples of how the method can be utilized.

Stout hearted Tōtara standing straight and true. The sapwood surrounds the heart-wood beneath (Tai 1992, p. 36)

\section{Ngā Paiaka-The roots (beginnings, whakapapa, connection to land)}

The roots of the Tōtara represent connection to the land. Symbolically, the Totara can be viewed as representing everything for Māori that roots us, anchors us, identifies us and locates us in te ao Māori (Māori world). The roots in the symbolism of the Tōtara mark out a genealogical reference point and tie us to the natural world, the whenua (land) and our ancestral rohe (territory). Our roots, our whakapapa, lead us to forge identities and bonds within our (family); iwi (tribe) and hapū (subtribe). The symbolism of the Tōtara as a symbol of rootedness to that place called home, for Māori, has become a symbol of nostalgia in a society which has become increasingly urbanized.

For Māori, reflecting on their roots and their whakapapa, they may well begin by reciting their pepeha (Māori device for introducing the Self). The pepeha contains genealogy and geographical reference points for the different iwi (tribes) and hapu (sub-tribes) throughout the country (Mutu 2001). The pepeha is central to one's identity and helps foster whanaungatanga (connections). It is also used to teach te reo Māori (Māori language) and is a central element to Māori language revitalization (Mutu 2001). The concept of pepeha can be understood by breaking the word down into two parts; pepe meaning "baby" and ha meaning "breath". The pepeha is metaphorically breathing life into an individual and connecting him or her with their genealogy. The pepeha locates the person by naming her/his traditional home place and by identifying the mountain, river, and meeting place associated with the person's whakapapa. It will also identity the person's iwi (tribe), hapu (subtribe) and the waka (mode of transport that brought him or her to Aotearoa New Zealand (Mutu 2001).

Utilizing Ko te rākau hei tohu mō te rangahau me te tuhi whakapapa method enables the narrator, or biographer to begin to think about their own life story or their subject(s) by using the roots of the tree as a prompt to reflect on origins and whakapapa (genealogy). Tree Symbolism and "Tree of Life" methods can also be applied to a variety of contexts. community groups, business, institutions and the like can also draw on the metaphor of the roots of a tree to reflect on their origins. Iliopoulou (2009) uses a "Tree of Life" method to work with community groups. She also uses the symbol of the roots of a tree for group members to begin to tell their stories. The roots represent where they come from (village, town, country) and their family histories (origins. Family name, ancestry, extended family), names of people who have taught them the most in life, their favourite place at home, a treasured song or dance (Iliopoulou 2009, p. 2).

Iliopoulou (2009) uses the tree of life as a counselling method to assist people who have been affected by trauma or medical or family and societal problems. Participants are invited to draw a tree with attention paid to the roots, the ground, the trunk, the branches, the leaves and fruit. A participant in her workshop wrote the following when reflecting on her roots. "[It] enabled me to look at what is important to me and honour my roots and find who have helped me to become the person I am and ... will be".

The tree of life workshops also have a second part, 'the forest of life', where participants write words of appreciation on each other's tree images. The third part to the workshops is 'the storms of life' where participants are invited to talk about some of the difficulties and challenges they may be experiencing in life (Iliopoulou 2009). 
Iliopoulou (2009) drew on the work of Ncube (2006) when they developed their tree of life counselling method. Ncube created an adaptation of the 'Tree of Life' exercise informed by narrative therapy principles and practices to support children affected by HIV / AIDS poverty and conflict. As with the counselling model utilized by Iliopoulou (2009) Ncube used the roots of the tree as a metaphor to invite children to think and write about their ancestry, origins and family history.

Jessica Senehi (2015) also draws on the tree of life tool in her work on pace and conflict. She views the 'Tree of Life' as offering a discreet way to talk about the self where people can disclose what they want to. 'The Tree of Life' may also be viewed as a more natural process of artwork and conversation over which participants have control as compared to traditional therapeutic sessions. As a therapeutic tool, 'the Tree of Life', offers opportunities for the emergence of diverse stories and connections in a culturally sensitive manner (Senehi 2015).

Whitinui (2013) argues there appears to be an inherent lack of knowing how to frame the "self" as an indigenous qualitative method of inquiry. Nevertheless, utilizing a tree metaphor for therapeutic work or for writing the Self could be one method of inquiry that does enable a framing of the Self that is both distinctly Māori, or could be adapted for other cultures. The initial reflection on origins, or our roots, our whakapapa or genealogy could not only help to frame the Self but also contextualize the Self within wider cultural, political, and social meanings and contexts.

An underlying premise throughout this article is that Ko te rākau hei tohu mō te rangahau me te tuhi whakapapa is an appropriate and well-suited method for carrying out research into the life stories and social histories of Māori. It provides a site or space for Māori to write about whakapapa and individual and group experience within tribal and social histories. The essential Māori self is intrinsically linked to whakapapa which proclaims the origins of individuals and communities and can serve as a vehicle for research as well as a descriptive medium for a range of inter-generational and co-generational relationships (Hemara 2000; Pihama 1993; Smith 1981). As a method for researching and writing whakapapa it can be viewed as a tool for finding the indigenous 'voice' or voicing concerns as they relate to research (Smith 1999). Beginning at the roots of the tree symbolism creates a process that aligns with what Whitinui (2013) describes as "constructing a culturally distinct method of inquiry that may readily coexist in the fabric of other people's lived experiences".

For Betty Wark (of Ngā puhi iwi or tribe) the roots of the Tōtara represented her whakapapa and her childhood growing up in the Hokianga region in the far north, of the North Island of New Zealand. As a symbol of nostalgia they provided her with feelings of belonging and being rooted in the Hokianga, the place of her birth and the place where she wanted to be returned to after her death (Connor 2006). Similarly, in her autobiography Kura Taylor (2018) describes her whakapapa as being firmly rooted in her ancestry of Te Âtiawa wi (tribe) located in the small Taranaki township of Waitara.

In both these examples, the metaphor of the roots of the tree, locate these two Mãori women within a specific geographic location, emphasizing that connection to the land remains very important for maintaining a sense of Māori identity within contemporary society. Māori identity is positioned in terms of physical and cultural geographies, whakapapa and tupuna (ancestors). Notions of turangawaewae (a place to stand) and papakainga (home place) and connection to traditional land remains very important for maintaining a sense of Māori identity within contemporary society. Whakapapa connects the tangata whenua (people of the land) to a particular area of land and to a particular marae (meeting place) (Tauroa and Tauroa 1993).

The metaphor of the tree roots reinforces, that, for Māori and other first peoples, the earth is sacred and considered a precious gift. In the Māori language it is no coincidence that the word, whenua, means both land and placenta. The land offers both nourishment and sustenance just as the placenta does to the developing foetus (Pere 1991). After a child is born and the whenua is expelled, it is returned to Papatūannuku as a sign that the child will continue to grow and develop just as he or she did inside the mother's uterus 
(Barlow 1993). In traditional Māori society, the whenua would be buried in a specific area of land which served to legitimate the child's turangawaewae within their iwi (Sinclair 1998). From a Māori perspective, the land and the people are intimately connected. "Te whenua ki te whenua. The body and the land are one. There is no separation" (Kahukiwa and Potiki 1999, p. 62).

\section{Tīwia-The Trunk (what sustains us?)}

The trunk of the Tōtara is stout and sturdy with rough reddish-brown bark that comes off in strips (Simpson 2017). The trunk of the Tōtara symbolises life and growth. It forms a link between the primal parents, Papatūānuku and Ranginui who were separated by Tane-Mahuta, the atua of the forests. When the trunk of the Totara is carved into poupou (posts) for a whare (house), it continues to form a connection between Papatūanuku and Ranginui, with its base in the earth and its tip reaching up through the rafters towards the sky. Both literally and metaphorically, the trunk of a tree offers sustenance.

With reference to the whakatauki (proverb) that opened this section, the concealed heart-wood within each of us symbolizes the pilgrimage on which we can all set forth to identify those cultural practices which sustain and nurture. This is in essence, what the trunk in the Ko te rākau hei tohu mō te rangahau me te tuhi whakapapa method represents; those practices which sustain and nurture us.

The Tōtara is regarded as a noble tree, being the child of Tane-Mahuta and the forest goddess Mumuwhango (Neich 2001). Before a Tōtara could be felled, permission had to be sought from Tane-Mahuta via appropriate ritual and karakia (invocations) (Irwin 1984). Such rituals are indicative of the great respect Māori have for the domain of Tane-Mahuta.

In Ko te rākau hei tohu mō te rangahau me te tuhi whakapapa method the trunk of the tree symbolises life, growth, sustenance and what sustains us. In the narrative of Betty Wark the trunk of the Tōtara tree represented her spirituality as a Catholic and her identity as Māori. These two seemingly contradictory traditions, Catholicism and Māoritanga (Māori culture, practice and beliefs) provided her with a sense of personal identity and a sense of community life (Connor 2006).

The inclusion of narratives which are constructed around the spiritual or invisible worlds are frequently represented as 'irrational' narratives (Postman 1995). Nevertheless, spiritual practices do provide sustenance and a construction of a narrative that gives life meaning (Batten 1995). Spiritual narratives provide complex and symbolic power to enable us to organise our lives around them and are aptly captured by the trunk of the tree metaphor.

Postman (1995) describes such narratives as great narratives and argues that we cannot do without them: "We are the god-making species. Our genius lies in our capacity to make meaning through the creation of narratives that give point to our labours, exalt our history, elucidate the present, and give direction to our future" (p. 6).

Not all narratives of sustenance will relate to the spiritual though. For Kura Taylor, the symbolism of the tree trunk and what sustained her related largely to her career as a primary school teacher and the senior positions she held both in education and in the primary teachers' union, the NZEI and the Teachers' Registration Board (Taylor 2018). While career narratives can also be symbolized in the branches of a tree, they can also become a dominant narrative in terms of providing meaning and sustenance to one's life. Postman (1995) points out that through the medium of narrative, life has a purpose whatever that narrative may be. A career narrative can certainly provide purpose and meaning, yet they can also do the opposite when jobs are lost, or a career path closes with the onset of new technology. When this happens, we will often create new narratives to give meaning to our lives and look for new opportunities and career pathways. On her retirement from teaching, Kura Taylor became very involved in the Ngahina Trust. Describing herself as becoming a "cultural navigator in her third age", she envisaged her post-retirement years as sustaining her in ways she had never foreseen, as she helped expand and grow Ngahina Trust and Ngahina Developments Limited (Taylor 2018). 
Kura Taylor's identity as Māori and belonging to the rohe (region) of Taranaki, on the west coast of New Zealand was also another aspect of her Self, that sustained her. While the roots of the tree anchor her to Taranaki and her tupuna (ancestors) her identity also sustained her. The culture, knowledge, beliefs and values she learnt as a child provided security and strength in her identity. Using the tree metaphor of the trunk, her identity can be captured by the metaphorical skin of the trunk. The rough reddish-brown bark of the Totara, like the skin of the human physical body, formed a boundary, an interface between the physical environment and the world beyond. Reflecting on her identity, Kura articulated her Māori skin with its brown hue and smooth texture as being central to her identity as Māori, sustaining her across the landscapes of her life (Taylor 2018).

The trunk of a tree can also symbolically represent significant events in the life of an individual or collective group. In his work with vulnerable children, Ncube (2006) utilized the trunk as a prompt for children to draw representations of events (both positive and challenging) that had impacted their lives.

This reinforces the notion that metaphors and symbols can signify both personal and collective representations and can be seen as containers of meaning and transformation and accordingly be adapted to specific contexts and situations. Metaphors and symbols in the context of tree symbolism can be used as literary devices for the construction of life narrative research which is both culturally appropriate and practical. Constructing a narrative around a particular symbol also provides a space for creativity, innovation and connection, enabling representation of cultural identity and promoting transcultural understanding as stories are read and shared across diverse communities.

\section{$N g \bar{a}$ Kāpeka The Branches (paths we have travelled)}

When grown in the open, the young Tōtara bears branches and leaves right down to the ground. The leaves are stiff and prickly to touch. The branches of the Tōtara can be viewed as representing the various paths open to the children of Tane-Mahuta. This metaphorical interpretation of the branches renders them as celestial branches, symbolising the baskets of knowledge. Māori mythology relates that Tane-Mahuta obtained the three baskets of knowledge for human kind; the basket of virtues, the basket of ritual formulae and the basket of evil (Best 1974). In the secular world the branches represent the varied and different paths we traverse throughout our lives.

In Ko te rākau hei tohu mō te rangahau me te tuhi whakapapa method the branches of the tree represent the various paths we take throughout our lives. The branches can symbolize both our private and public selves. For many people the branches will include our education, our work, our personal relationships and the ways in which we contribute to our communities. The branches may also be representative of gender, class and ethnicity. For Betty Wark who was a young woman in the 1950s, the work she entered into was in a predominantly female sector, that of housekeeper/cook. As a young Māori woman, she had been equipped for domestic work and did not branch out into other work until in her mid-life.

Marriage and motherhood were also crucial sites regarding the construction of femininity in Betty Wark's life. For women in the 1950s and 1960s, marriage and motherhood represent a major branch in the lives of most heterosexual women at this time. Motherhood was viewed as every woman's potential biological destiny and was seen as a necessary social duty for married women (Matthews 1984).

Morally and economically, single motherhood was a contradiction in terms, and until the 1960s a woman giving birth to a child outside of marriage was constructed as being an unfit mother (Matthews 1984). For Kura Taylor, the branches of her life did not encompass marriage. As a single woman with a career in education, she had no desire to marry. When she became pregnant, she did not contract a hasty marriage, demonstrating, her determination to resist popular discourses on the construction of the feminine ideal. Nevertheless, ideologies defining unmarried mothers as unfit, forced Kura to keep her baby a secret and the baby was raised by her mother. 
While, a narrative may not necessarily overtly discuss the 'branches' of an individual's life history, they can be useful prompts. For example, questions such as "Can you tell me about the different branches your life took?", or, "How did you branch out after leaving school?" can help individuals recall the varying facets their lives have taken, the different jobs, the various causes they have been involved in, the ways in which they became leaders and so on.

When Kura Taylor (2018) wrote her autobiographical narrative, she reflected on her life, using a variety of memory triggers. The metaphor of the tree was particularly helpful, especially, when she started considering the varied branches her life had taken, and the family members, peers, friends, mentors, co-workers, fellow Trust members and the like she had interreacted with throughout her life.

\section{Rākau Whai Hua-The Fruits (maturity, fruits of our labours)}

Fruits, in tree symbolism, represent maturity, fertility, offspring and nourishment. The bright red fruit of the Tōtara tree were a valued food in traditional Māori society. The fruits are sweet and juicy with a slight pine flavour and are only produced by the female tree (Crowe 1992). The fruits in the Ko te rākau hei tohu mō te rangahau me te tuhi whakapapa method represent those aspects of our mid to later life that connect us to our communities and enable our life's work or our legacy to come to fruition. The "fruits" of our lives can sometimes manifest as a period in later life, where we have more time for ourselves. Children may have grown into adulthood and left home. There may be grandchildren to enjoy. It might be a time when things we put off in our youth become available to us such as travelling, study, taking up new hobbies or becoming a volunteer for community groups.

In the life narrative of Betty Wark, the "fruits" of her life evolved into a deeper commitment to her 'heart politics'. The term 'heart politics' denotes having the courage to overcoming one's fears and take risks. To become involved in heart politics is to become involved in community, grassroots initiatives with a one-pointed commitment to social transformation. Heart politics also means having a feeling of connectedness with the people or the cause you are fighting for (Peavey 1986).

In the autobiographical life narrative of Kura Taylor (2018), the "fruits" of her life also evolved into a deeper commitment to her 'heart politics' which in her case manifested as working for the Ngahina Trust. Her retirement not only enabled her to use the extra time she had but it also enabled her to utilize the skills she had honed over her career as a leader in education and the primary teachers' union. Metaphorically, the fruits of her work with Ngahina Trust also connected her to her whakapapa and Māori identity.

The strength of Ngahina Trust lies within whakapapa, genealogy, that began in the Maori Cosmology, descending to, more recently, Ihakara te Ngarara, and continuing down through his sons Epiha, Teira (my father's great-grandfather), and Te Wharemaru. The Ngahina Trust was named to honour the late Ngahina Metapere Teira Taiaki, our father's sister, who was a Beneficial Owner. Implicit in the naming was recognition of the tupuna, ancestors, as well as owners of the same generation as Ngahina Metapere Teira Taiaki, who had supported her in land retention endeavours. (Taylor 2018, p. 152)

\section{Ngāherehere-The Forest (Collective narratives)}

Collective life histories and narratives can metaphorically be viewed as being part of a forest or ngaherehere. The forest in the Ko te rākau hei tohu mō te rangahau me te tuhi whakapapa method represents our connections to others, to family, friends and community, how we interact within the collective. Collective narratives and life stories of Māori have the potential to reclaim and reinterpret both historical and contemporary issues of culture, gender, spirituality and conceptualizations of the self. The act of writing, of engaging with language that affirms and revitalizes, opens possibilities for change. Collective biographical writing has the potential to position its subject, the social actors contained in the text, on that threshold where a pluralized self can evolve. A pluralized self-identity is, as Keating (1996) 
suggests, capable of interacting with many worlds. Writing collective biographical subjects as flexible, evolving identities assumes complex speaking positions enabling points of similarity and difference.

One of the strengths of Mãori collective narratives is that they provide a context for different voices to dialogue with such issues as authenticity and identity. Despite the potentially contentious issue of authenticity, collective narratives give voice to the subject, substantiating and validating the lived experience. For Māori, collective narratives not only position us as the subjects of our own inquiry but also provide a space for articulating our multiple lives and identities. Writing about lived experience for Māori has evolved through our history of colonization and the need to subvert the social relations of dominance and subordination that came with colonization. Collective narratives of Māori can demonstrate the complex interconnections between our past and present illustrating the continuous shifts in our cultural identities. As Keating (1996) argues, cultural identities have histories and undergo continual transformations in complex interactions with other categories of meaning; individual and collective identities are hybrid creations, not organic pre-existing discoveries. By writing about collectives, Māori subjects can exert control over the ways our lives are represented.

\section{Conclusions}

This article has discussed Ko te rākau hei tohu mō te rangahau me te tuhi whakapapa method for writing genealogy based on the symbolism of the tree. This method has been put forward as being appropriate for documenting the life stories, personal narratives and auto/biographies of Māori. As such it can be considered as kaupapa Māori research (Māori philosophical approach to research). The article also contends that the method is suitable for a range of ethnic groups and also community groups.

An incorporation of other Māori methods of narrative research was not possible within the limitations of this article. Nor, has the article engaged with methods of narrative analysis. Nevertheless, it is important to point out that many Māori researchers are engaged in scholarship that explores methods that utilize story pürākau (story-telling), narrative inquiry, indigenous approaches to autobiography, autoethnography and the like. In traditional Maori society pürākau (story-telling) generally referred to Māori myths and legends. Yet, as Lee (2009) argues pürākau can also be viewed as a traditional form of Māori narrative, rich in philosophical thought and epistemological constructs that are fundamental to Maori world views and identity. Ware et al. (2017) have developed a narrative inquiry method which also draws on pūrākau (story-telling). Kaupapa Kōrero provides a framework achieved through körero (telling stories) which allows people to locate themselves in their world, both figuratively and in relation to their ancestors and future descendants. Similarly, Whitinui (2013) draws on story-telling in his articulation of what might constitute a distinctly indigenous approach to autoethnography. For Whitinui (2013, p. 11), "indigenous autoethnography has a central aim to "construct" stories that invoke a deep sense of appreciation for multiple realities and lives concerning indigenous peoples' ways of knowing and to protect our existence as Māori, "Native", or being indigenous".

One of the benefits of utilizing a method such as Ko te rākau hei tohu mō te rangahau me te tuhi whakapapa for Māori is that it can incorporate elements that are distinctly Māori and can augment Māori cultural identity. In order for a conception of cultural identity to play a critical role in post-colonial struggles, it must reflect the common historical experiences and shared cultural codes within a stable, unchanging and continuous frame of reference and meaning (Hall 1998). In post-colonial Aotearoa New Zealand society, the resurgence of a Māori cultural identity reflects Hall's definition. The common historical experiences of colonization and the fragmentation of Māori identity have been positioned in nostalgic narratives of the past. In auto/biographical work the re-telling of the past and telling stories of whakapapa emphasise common points of similarity, such as attachment to the land. In the Ko te rākau hei tohu mō te rangahau me te tuhi whakapapa method, these histories of cultural 
and self-identity are prompted via the metaphor of Nga Paiaka-the roots, beginnings, whakapapa and connection to land.

Drawing on the importance of whakapapa (genealogy) as a source of connection for all Māori and as a distinguishing feature of Māori culture, the Ko te rākau hei tohu mō te rangahau me te tuhi whakapapa method can provide a framework for Māori to articulate notions of our collective selves which include cultural, socio-political and historical memories. Māori collective biography can represent lives within a collective context that incorporates narratives and stories related to being Māori using the metaphor of Ngāherehere-the Forest (Collective narratives).

Metaphors and symbols reveal different planes of reality and in terms of identity and life narratives represent what has personal significance for both individuals and groups. Metaphors and symbols as a literary device enable the telling of stories in ways which both connect and empower the narrator and subject(s). They can help narrators talk about aspects of their lives in insightful and creative ways including drawing and other art mediums. They can also address collective cultural identity where there are shared meanings of symbols as well as individual meanings.

The tree of life is growing where the spirit never dies, and the bright light of salvation shines in dark and empty skies. Bob Dylan (1988), “Death is Not the End".

Funding: This research received no external funding.

Institutional Review Board Statement: Not applicable.

Informed Consent Statement: Not applicable.

Data Availability Statement: Not applicable.

Acknowledgments: A big thank you to Hēmi Dale, Director Māori Medium Education, Te Puna Wānanga, University of Auckland, for his generosity and assistance with naming the research method, Ko te rākau hei tohu mō te rangahau me te tuhi whakapapa.

Conflicts of Interest: The author declares no conflict of interest.

\section{References}

Barlow, Cleve. 1993. Tikanga Whakaaro: Key Concepts in Māori Culture. Oxford: Oxford University Press.

Batten, Juliet. 1995. Celebrating the Southern Seasons: Rituals for Aotearoa. Auckland: Tandem Press.

Best, Elsdon. 1974. The Māori as He Was. Wellington: A.R. Shearer, Government Printer.

Caro, Tina. n.d. Oak Tree Symbolism and Meaning. Available online: https://magickalspot.com/oak-tree-symbolism-meaning/ (accessed on 5 January 2021).

Castelow, Ellen. n.d. The English Oak. Available online: https://www.historic-uk.com/CultureUK/The-English-Oak/ (accessed on 10 December 2020).

Clarke, Eileen. 2006. From Kaitiaki to branch office: The bureaucratisation of whakapapa. AlterNative: An International Journal of Indigenous Peoples 2: 138-73. [CrossRef]

Connor, Helene. 2019. Whakapapa Back: Mixed Indigenous Māori and Pākehā Genealogy and Heritage in Aotearoa/New Zealand. Genealogy 3: 73. [CrossRef]

Connor, Helene. 2006. Writing Ourselves 'Home'. Biographical Texts: A Method for Contextualizing the Lives of Wahine Māori; Locating the Story of Bety Wark. Unpublished Ph.D. thesis, University of Auckland, Auckland, New Zealand.

Crews, Judith. 2003. Forest and tree symbolism in folklore. Unasylva 54: 37-43. Available online: http://www.fao.org/3/y9882e/y988 2e08.htm (accessed on 9 December 2020).

Crowe, Andrew. 1992. Which Native Tree? Auckland: Viking Pacific.

Dylan, Bob. 1988. Death is Not the End [Song]. In Down in the Groove. New York: Columbia Records.

Hall, Stuart. 1998. Cultural identity and diaspora. In Identity, Community, Culture, Difference. Edited by Jonathan Rutherford. London: Lawrence and Wishart, pp. 222-37.

Hemara, Wharehuia. 2000. Māori Pedagogies: A View from the Literature. Wellington: New Zealand Council for Educational Research.

Hudson, Maui L., Annabel LM Ahuriri-Driscoll, Marino G. Lea, and Rod A. Lea. 2007. Whakapapa-A Foundation for Genetic Research? Bioethical Inquiry 4: 43-49. [CrossRef]

Iliopoulou, G. 2009. The "Tree of Life" in a Community Context. Available online: https://dulwichcentre.com.au/wp-content/ uploads/2014/01/tree-of-life-community-context.pdf (accessed on 30 November 2020). 
Irwin, James. 1984. An Introduction to Māori Religion. Bedford Park: Australian Association for the Study of Religions.

Kahukiwa, Robyn, and Roma Potiki. 1999. Oriori: A Māori Child is Born. Auckland: Tandem Press.

Keating, AnaLouise. 1996. Women Reading, Women Writing: Self-Invention in Paula Gunn Allen, Gloria Anzaldúa and Audre Lorde. Philadelphia: Temple University Press.

Lee, Jenny. 2009. Decolonising Māori narratives: Pūrākau as a method. Mai Revieww 2: 1-12. Available online: http://www.review.mai. ac.nz/mrindex/MR/article/download/242/242-1618-1-PB.pdf (accessed on 8 January 2021).

Leroy, Thibault, Christophe Plomion, and Antoine Kremer. 2019. Oak symbolism in the light of genomics. The New Phytologist 226: 1012-17. [CrossRef] [PubMed]

Mahuika, Nēpia. 2019. A brief history of whakapapa: Māori approaches to genealogy. Genealogy 3: 32. Available online: https: / / www.mdpi.com/2313-5778/3/2/32 (accessed on 8 January 2021). [CrossRef]

Mark, Glenis, and Amohia Boulton. 2017. Indigenising photovoice: Putting Māori cultural values into a research method. Forum: Qualitative Social Research 18: 19. [CrossRef]

Matthews, Julius. 1984. Good and Mad Women: The Historical Construction of Femininity in Twentieth-Century Australia. Sydney: George Allen and Unwin.

Mutu, M. 2001. Ko Piiwheke Te Maunga- Piiwheke is the mountain. Māori language and Māori ethnic identity: Reaffirming identity through language revitalisation. He Pukenga Korero Ngahuru, A Journal of Māori Studies 6: 1-8. Available online: http:/ / ndhadeliver.natlib.govt.nz/delivery/DeliveryManagerServlet?dps_pid=IE22164306 (accessed on 8 January 2021).

Ncube, N. 2006. The Tree of Life Project [online]. International Journal of Narrative Therapy \& Community Work 1: 3-16. Available online: https:/ / narrativetherapycentre.com/wp-content/uploads/2020/12/Tree-of-Life-by-Ncazelo-Ncube-2006.pdf (accessed on 18 January 2021).

Neich, Roger. 2001. Carved Histories: Rotorua Ngati Tarawhai Woodcarving. Auckland: Auckland University Press.

Peavey, Fran. 1986. Heart Politics. Philadelphia: New Society Publishers.

Pere, Rangimarie Rose. 1991. Te Wheke: A Celebration of Infinite Wisdom. Gisborne: Ao Ako Global Learning New Zealand Ltd.

Pihama, Leonie. 1993. No I will not be a post. Te Pua 2: 2.

Pomare, Maui, and James Cowan. 1930. Legends of the Māori. Wellington: Whitcombe and Tombs. Available online: http://nzetc. victoria.ac.nz//tm/scholarly/tei-Pom01Lege-t1-front-d1-d1.html (accessed on 18 January 2021).

Postman, Neil. 1995. The necessity of gods. In The End of Education: Redefining the Value of School. Edited by Neil Postman. New York: Knopf, pp. 1-18.

Ratka, Relic. 2017. Esoteric Symbolism of the 'Tree of Life': A Cross-cultural Perspective. Journal of Human Values 23: 73-80. [CrossRef]

Senehi, Jessica. 2015. Our tree of life in the field: Locating ourselves in the peace and conflict studies field through the tree of life experience. Peace Research 47: 10-28. Available online: https://www-proquest-com.ezproxy.auckland.ac.nz/docview/18660519 29? accountid=8424 (accessed on 20 January 2021).

Simpson, Philip. 2017. Tōtara: A Natural and Cultural History. Auckland: University of Auckland Press.

Sinclair, Moana. 1998. Pakeha land legislation in Aotearoa: The continuous resistance by Māori women. In Indigenous Women: The Right to a Voice. Edited by Diana Vinding. Copenhagen: IWGIA, pp. 92-102.

Smith, Jean. 1981. Self and experience in Māori culture. In Indigenous Psychologies and the Anthropology of the Self. Edited by Paul Heelas and Andrew Lock. London: Academic Press, pp. 145-59.

Smith, Linda Tuhiwai. 1999. Decolonizing Methodologies: Research and Indigenous Peoples. New York: St. Martin's.

Tai, R. 1992. He Taonga Whakahirahira: Treasures That Energise. Hamilton: Wenetia Publications.

Tauroa, Hiwi, and Patricia Tauroa. 1993. Te Marae: A Guide to Customs and Protocol. Auckland: Reed.

Taylor, Kura Marie Teira. 2018. Te Atiawa Paake: Reflections on the Playgrounds of My Life. Unpublished Ph.D. Thesis, Stout Research Centre, Victoria University, Wellington, New Zealand. Available online: http:/ / researcharchive.vuw.ac.nz/handle/10063/7079 (accessed on 20 January 2021).

Tocker, Kimai. 2017. Living and learning as Māori: Language stories from three generations. Australian Journal of Indigenous Education 46: 115-25. [CrossRef]

Ware, Felicity, Mary Breheny, and Margaret Forster. 2017. Kaupapa Kōrero: A Māori cultural approach to narrative inquiry. AlterNative: An International Journal of Indigenous Peoples. [CrossRef]

Whitinui, Paul. 2013. Indigenous Autoethnography: Exploring, Engaging, and Experiencing "Self" as a Native Method of Inquiry. Journal of Contemporary Ethnography. [CrossRef] 